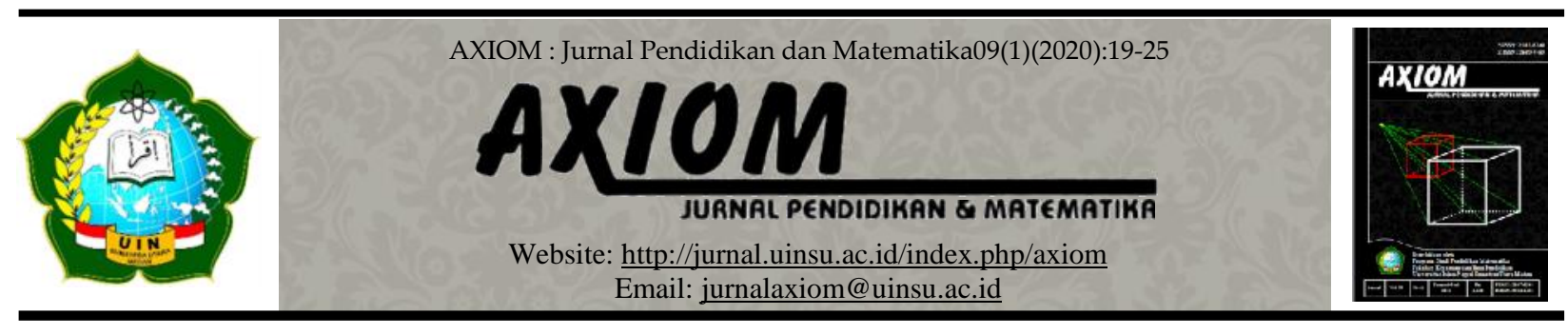

\title{
PERBEDAAN KEMAMPUAN PEMAHAMAN KONSEP DAN PEMECAHAN MASALAH MATEMATIS SISWA YANG MEMPEROLEH MODEL PEMBELAJARAN BERBASIS MASALAH DAN PEMBELAJARAN EKSPOSITORI
}

Oleh:

\author{
Wina Alnadrah Pulungan ${ }^{1}$, Eka Khairani Hasibuan ${ }^{2}$ \\ ${ }^{1}$ Pendidikan Matematika, Fakultas Ilmu Tarbiyah dan Keguruan, Universitas Islam Negeri \\ Sumatera Utara \\ ${ }^{2}$ Pendidikan Matematika, Fakultas Ilmu Tarbiyah dan Keguruan, Universitas Islam Negeri \\ Sumatera Utara \\ E-mail: ${ }^{1}$ winapulungan97@gmail.com, ${ }^{2}$ ekakhairani@uinsu.ac.id
}

doi : 10.3082/axiom.v\%vi\%i.7233

\begin{abstract}
Abstrak:
Penelitian ini bertujuan untuk: (1) mengetahui apakah kemampuan pemahaman konsep matematis siswa yang memperoleh model pembelajaran berbasis masalah lebih baik daripada siswa yang memperoleh model pembelajaran ekspositori, (2) mengetahui apakah kemampuan pemecahan masalah matematis siswa yang memperoleh model pembelajaran berbasis masalah lebih baik daripada siswa yang memperoleh model pembelajaran ekspositori, (3) mengetahui apakah kemampuan pemahaman konsep dan pemecahan masalah matematis siswa yang memperoleh model pembelajaran berbasis masalah lebih baik daripada siswa yang memperoleh model pembelajaran ekspositori. Jenis penelitian ini ialah penelitian kuantitatif, dengan pendekatan penelitian quasi eksperimen. Populasi penelitian ini adalah seluruh kelas X SMA Negeri 1 Binjai Kab. Langkat yang terdiri dari 7 kelas, dan sampel pada penelitian ini yaitu kelas X-IPA 1 (kelas eksperimen) sebanyak 30 siswa dan kelas X-IPA 2 (kelas kontrol) sebanyak 30 siswa. Teknik pengambilan sampel dilakukan dengan menggunakan teknik cluster random sampling. Pengujian hipotesis dilakukan dengan analisis varians dan dilanjutkan dengan uji tuckey pada taraf signifikan 0,05. Hasil temuan ini menunjukkan: (1) kemampuan pemahaman konsep matematis siswa yang memperoleh model pembelajaran berbasis masalah lebih baik daripada siswa yang memperoleh model pembelajaran ekspositori, (2) kemampuan pemecahan masalah matematis siswa yang memperoleh model pembelajaran berbasis masalah tidak lebih baik daripada siswa yang memperoleh model pembelajaran ekspositori, (3) kemampuan pemahaman konsep dan pemecahan masalah matematis siswa yang memperoleh model pembelajaran berbasis masalah lebih baik secara signifikan dengan siswa yang memperoleh model pembelajaran ekspositori.
\end{abstract}

Kata Kunci:

Kemampuan Pemahaman Konsep, Kemampuan Pemecahan Masalah, Pembelajaran Berbasis masalah, dan Pembelajaran Ekspositori

\section{Abstract:}

This study aims to: (1) determine whether the ability to understand mathematical concepts of students who get problem-based learning models is better than students who get expository learning models, (2) find out whether the mathematical problem-solving abilities of students who 
get problem-based learning models are better than students who get expository learning models, (3) know whether the ability to understand concepts and mathematical problem solving students who get a problem-based learning model is better than students who get expository learning models. This type of research is quantitative research, with a quasi-experimental research approach. The population of this study were all class X SMA Negeri 1 Binjai, Langkat Regency which consisted of 7 classes, and the sample in this study was X-Science 1 (experimental class) of 30 students and $30 \mathrm{X}$-Science 2 (control class) of 30 students. . The sampling technique is done by using cluster random sampling techniques. Hypothesis testing is done by analysis of variance and followed by tuckey test at a significant level of 0.05. These findings indicate: (1) the ability to understand mathematical concepts of students who get a problem based learning model is better than students who get expository learning models, (2) the ability to solve mathematical problem students who get a problem based learning model is no better than students who get expository learning models, (3) the ability to understand concepts and mathematical problem solving students who get a problem-based learning model is significantly better than students who get expository learning models

\section{Keywords:}

Concept Understanding Ability, Problem Solving Ability, Problem Based Learning, and Expository Learning

\section{A. Pendahuluan}

Pendidikan merupakan faktor utama yang menentukan kualitas suatu bangsa. Pendidikan merupakan suatu proses penanaman pengetahuan, keterampilan, dan sikap pada peserta didik yang memungkinkan nantinya mereka mampu menjadi warga masyarakat yang bertanggung jawab. Tujuan pendidikan dalam Undang-Undang RI Nomor 20 Tahun 2003, Bab II Pasal 3 disebutkan bahwa Pendidikan Nasional berfungsi mengembangkan kemampuan dan membentuk watak serta peradapan bangsa yang bermartabat dalam rangka mencerdaskan kehidupan bangsa, bertujuan untuk mengembangkan potensi peserta didik agar menjadi manusia yang beriman dan bertakwa kepada Tuhan Yang Maha Esa, berahklak mulia, sehat, berilmu, cakap, kreatif, mandiri, dan menjadi warga negara yang demokratis serta bertanggung jawab.

Matematika merupakan salah satu bagian yang penting dalam bidang ilmu pengetahuan. Apabila dilihat dari sudut pengklasifikasian bidang ilmu pengetahuan, matematika termasuk ke dalam ilmu-ilmu eksakta yang lebih banyak memerlukan pemahaman dari pada hapalan. Untuk dapat memahami suatu pokok bahasan dalam matematika, siswa diharapkan mampu memiliki kemampuan matematis yang berguna untuk menghadapi tantangan global. Kemampuan tersebut diantaranya kemampuan pemahaman konsep dan pemecahan masalah matematis, yang merupakan kemampuan yang sangat diperlukan oleh setiap orang dalam menyelesaikan permasalahan kehidupan serta menghadapi tantangan global saat ini.

Berdasarkan hasil observasi yang dilakukan oleh penulis sebagai peneliti di SMA Negeri 1 Binjai Kab. Langkat dan wawancara dengan bapak Iswa Oktaya, S.Pd sebagai guru matematika di sekolah tersebut, dapat diperoleh keterangan bahwa adanya masalah yang dihadapi siswa dalam proses belajar di sekolah antara lain siswa kurang tertarik dan merasa bosan dengan pembelajaran matematika. Dalam pelaksanaan pembelajaran matematika guru jarang meminta siswa untuk memahami konsep dan aplikasi matematikanya sehingga siswa sangat sulit memecahkan sebuah masalah dimana siswa belum paham betul duduk permasalahannya atau konsepnya dalam memberikan penjelasan yang tepat, jelas, dan logis atas jawabannya. Siswa juga tidak dibiasakan untuk memecahkan permasalahan matematika yang membutuhkan rencana, strategi, dan mengeksplorasi kemampuan mengeneralisasi dalam penyelesaian masalahnya. Proses pembelajaran yang tidak tepat di kelas memberikan dampak terhadap lemahnya kemampuan pemahaman konsep dan kemampuan pemecahan masalah matematika siswa.

Menurut Sudirman (dalam Priansa, 2017) bahwa pemecahan masalah merupakan cara penyajian bahan pelajaran dengan menjadikan masalah sebagai titik tolak pembahasan untuk dianalisis dan disintesis dalam usahan mencari pemecahan atau jawabannya oleh peserta didik. 
Wina Alnadrah Pulungan \& Eka Khairani Hasibuan: Perbedaan Kemampuan Pemahaman Konsep dan Pemecahan Masalah Matematis Siswa yang Memperoleh Model Pembelajaran Berbasis Masalah dan Pembelajaran Ekspositori

Dengan pembelajaran berbasis masalah akan mengantarkan siswa untuk memahami konsep materi pelajaran dimulai dari belajar dan bekerja pada situasi masalah yang diberikan diawal pembelajaran, sehingga siswa memperoleh kebebasan untuk berpikir mencari penyelesaiannya dari masalah yang diberikan.

Terdapat beberapa hasil penelitian yang ada. Yelvalinda, Pujiastuti, \& Fatah (2019) menyatakan bahwa model pembelajaran based learning dapat meningkatkan kemampuan matematis. Gunantara, Suarjana, \& Riastini (2014) menunjukan bahwa penerapan model pembelajaran Problem Based Learning (PBL) dapat meningkatkan kemampuan pemecahan masalah. Situmorang (2016) memperlihatkan bahwa pembelajaran ekspositori efektif dalam meningkatkan pemahaman konsep matematika. Rizkiani, Ahmad, \& Lubis (2019) memperlihatkan bahwa pembelajaran ekspositori mampu meningkatkan kemampuan pemecahan masalah. Penelitian ini akan memperlihatkan perbedaan kemampuan pemahaman konsep dan pemecahan masalah matematis siswa yang memperoleh model pembelajaran berbasis masalah dan pembelajaran ekspositori.

\section{B. Kajian Teoritis}

Menurut Susanto (dalam Mawaddah \& Maryanti, 2016), pemahaman adalah suatu proses yang terdiri dari kemampuan untuk menerangkan dan menginterpretasikan sesuatu, mampu memberikan gambaran, contoh, dan penjelasan yang lebih luas dan memadai serta mampu memberikan uraian dan penjelasan yang lebih kreatif, sedangkan konsep merupakan sesuatu yang tergambar dalam pikiran, suatu pemikiran, gagasan, atau suatu pengertian. Sehingga siswa dikatakan memiliki kemampuan pemahaman konsep matematika jika dia dapat merumuskan strategi penyelesaian, menerapkan perhitungan sederhana, menggunakan simbol untuk memperesentasikan konsep, dan mengubah suatu bentuk ke bentuk lain seperti pecahan dalam pembelajaran matematika.

Menurut Sari (2017: 44) adapun indikator yang menunjukkan pemahaman konsep, antara lain: (1) menyatakan ulang sebuah konsep, (2) mengklasifikasikan objek-objek menurut sifatsifat tertentu (sesuai dengan konsepnya), (3) memberikan contoh dan non contoh dari konsep, (4) menyajikan konsep dalam berbagai bentuk representasi matematis, (5) syarat perlu atau syarat cukup suatu konsep, (6) menggunakan, memanfaatkan dan memilih prosedur atau operasi tertentu, dan (7) mengaplikasikan konsep atau algoritma pemecahan masalah. Sedangkan menurut Lestari \& Yudhanegara (2018: 84) kemampuan penyelesaian masalah matematika adalah kemampuan menyelesaikan masalah rutin, non-rutin, rutin terapan, rutin non-terapan, non-rutin terapan, dan masalah non-rutin non-terapan dalam bidang matematika. Masalah rutin adalah masalah yang prosedur penyelesaiannya sekadar mengulang secara algoritmik. Masalah non-rutin adalah masalah yang prosedur penyelesaiannya memerlukan perencanaan penyelesaian, tidak sekadar menggunkan rumus, teorema, atau dalil. Masalah rutin terapan adalah masalah yang dikaitkan dengan dunia nyata atau kehidupan sehari-hari. Masalah rutin non-terapan adalah masalah rutin yang prosedur penyelesaiannya melibatkan berbagai algoritma matematika. Masalah non-rutin terapan adalah masalah yang penyelesaiannya menuntut perencanaan dengan mengaitkan dunia nyata atau kehidupan sehari-hari. Masalah non-rutin nonterapan adalah masalah yang hanya berkaitan dengan hubungan matematika semata.

Adapun menurut Lestari \& Yudhanegara (2018: 85) indikator kemampuan penyelesaian masalah matematis, yaitu: (a) mengindentifikasi unsur-unsur yang diketahui, ditanyakan, dan kecukupan unsur yang diperlukan, (b) merumuskan masalah matematis atau menyusun model matematis, (c) menerapkan strategi untuk menyelesaikan masalah, dan (d) menjelaskan atau menginterpretasikan hasil penyelesaian masalah. Selanjutnya menurut Sanjaya (2013: 214) strategi pembelajaran berbasis masalah diartikan sebagai rangkaian aktivitas pembelajaran yang menekankan kepada proses penyelesaian masalah yang dihadapi secara ilmiah. Sedangkan menurut Tan (dalam Rusman, 2017: 333) pendekatan pembelajaran berbasis masalah merupakan inovasi dalam pembelajaran karena dalam PBM kemampuan kemampuan berfikir siswa betulbetul dioptimalisasikan melalui proses kerja kelompok atau tim yang sistematis, sehingga siswa 
dapat memberdayakan, mengasah, menguji, dan mengembangkan kemampuan berpikirnya secara berkesinambungan.

Sedangkan strategi pembelajaran ekspositori menurut Sanjaya (2013: 179) adalah strategi pembelajaran yang menekankan kepada proses penyampaian materi secara verbal dari seorang guru kepada sekelompok siswa dengan maksud agar siswa dapat menguasai materi pelajaran secara optimal. Kemudian menurut Roy Killen (dalam Sumantri, 2016: 62) menamakan langkah ekspositori ini dengan istilah pembelajaran langsung (direct instruction). Dalam sistem ini, guru menyajikan bahan dalam bentuk yang telah dipersiapkan secara rapi, sistematik dan lengkap sehingga siswa tinggal menyimak dan mencernanya secara teratur dan tertib. Siswa juga dituntut untuk menguasai bahan yang telah disampaikan tersebut.

\section{Metode Penelitian}

\section{Jenis Penelitian}

Penelitian ini bertujuan untuk mengetahui perbedaan kemampuan pemahaman konsep dan pemecahan masalah matematis siswa yang memperoleh model pembelajaran berbasis masalah dan pembelajaran ekspositori pada materi trigonometri di kelas X SMA Negeri 1 Binjai Kab. Langkat. Oleh karena itu, penelitian ini merupakan penelitian eksperimen dengan jenis penelitiannya adalah quasi eksperiment (eksperimen semu), sebab kelas yang digunakan telah terbentuk sebelumnya.

\section{Waktu dan Tempat Penelitian}

Penelitian ini akan dilaksanakan di SMA Negeri 1 Binjai Kab. Langkat, yang beralamat di Jln. Yos Sudarso Suka Makmur Kec. Binjai Kab. Langkat. Kegiatan penelitian dilakukan pada kelas X semester II Tahun Pelajaran 2018/2019. Penetapan jadwal penelitian disesuaikan dengan jadwal yang ditetapkan oleh kepala sekolah.

\section{Target/Subjek Penelitian/Populasi dan Sampel}

Populasi dalam penelitian ini adalah seluruh siswa kelas X SMA Negeri 1 Binjai Kab. Langkat kelas X yang terdiri dari 7 kelas dimana 5 kelas untuk IPA dan 2 kelas untuk IPS. Adapun sistem penarikan sampel yang digunakan adalah Cluster Random Sampling (sampel berkelompok) artinya setiap subjek dalam populasi memperoleh kesempatan dipilih menjadi sampel. Terpilih dua rombongan belajar dari tujuh kelas yang ada di SMA Negeri 1 Binjai Kab. Langkat. Kelas yang pertama yaitu kelas X IPA-1 yang akan diajarkan dengan pembelajaran Berbasis Masalah dan dijadikan kelas eksperimen dan kelas yang kedua yaitu kelas X IPA-2 yang diajarkan dengan pembelajaran Ekspositori yang dijadikan kelas kontrol.

\section{Prosedur}

Penelitian ini melibatkan dua kelas yaitu kelas eksperimen kelompok Pembelajaran Berbasis Masalah dan kelas kontrol kelompok Pembelajaran Ekspositori yang diberi perlakuan berbeda. Pada kedua kelas diberikan materi yang sama yaitu Trigonometri. Untuk mengetahui kemampuan pemahaman konsep dan kemampuan pemecahan masalah matematika siswa diperoleh dari tes yang diberikan pada masing-masing kelompok setelah penerapan dua perlakuan tersebut. 
Wina Alnadrah Pulungan \& Eka Khairani Hasibuan: Perbedaan Kemampuan Pemahaman Konsep dan Pemecahan Masalah Matematis Siswa yang Memperoleh Model Pembelajaran Berbasis Masalah dan Pembelajaran Ekspositori

\begin{tabular}{|l|c|c|}
\hline Kemampuan & $\begin{array}{c}\text { Pembelajaran Berbasis } \\
\text { Masalah }\left(\mathrm{A}_{1}\right)\end{array}$ & $\begin{array}{c}\text { Pembelajaran } \\
\text { Ekspositori }\left(\mathrm{A}_{2}\right)\end{array}$ \\
\hline Pemahaman Konsep $\left(\mathrm{B}_{1}\right)$ & $\mathrm{A}_{1} \mathrm{~B}_{1}$ & $\mathrm{~A}_{2} \mathrm{~B}_{1}$ \\
\hline Pemecahan masalah & $\mathrm{A}_{1} \mathrm{~B}_{2}$ & $\mathrm{~A}_{2} \mathrm{~B}_{2}$ \\
\hline
\end{tabular}

Gambar 1. Desain Penelitian

\section{Data, Intrumen, dan Teknik Pengumpulan Data}

Sesuai dengan teknik pengumpulan data yang digunakan, maka instrumen yang digunakan dalam penelitian ini adalah berbentuk tes. Tes adalah alat atau prosedur yang digunakan untuk mengetahui atau mengukur sesuatu dalam suasana, dengan cara dan aturanaturan yang sudah ditentukan (Arikunto, 2011). Tes tersebut terdiri dari tes kemampuan pemahaman konsep yang berjumlah 5 butir soal dan tes kemampuan pemecahan masalah yang berjumlah 5 butir soal. Dimana soal di buat berdasarkan indikator yang diukur pada masingmasing tes kemampuan pemahaman konsep dan tes kemampuan pemecahan masalah matematis siswa.

Sebelum dilakukan pengujian hipotesis, pada kelompok-kelompok data dilakukan pengujian Normalitas, untuk kebutuhan uji Normalitas ini digunakan teknik analisis Liliefors, sedangkan pada analisis uji Homogenitas digunakan teknik analisis uji Bartlett. Pengujian hipotesis statistik digunakan teknik ANAVA (analisis varians) yakni dengan membandingkan angka pada nilai koefisien $\mathrm{F}_{\text {hitung }}$ dengan $\mathrm{F}_{\text {tabel }}$ pada setiap faktor [model pembelajaran $(\mathrm{A})$ dan kemampuan siswa (B)] dan menganalisis interaksi antar faktor tersebut (A x B $)^{2}$.

\section{Hasil Penelitian dan Pembahasan}

Penelitian quasi eksperimen mengenai perbedaan kemampuan pemahaman konsep dan pemecahan masalah matematis siswa yang memperoleh model pembelajaran berbasis masalah dan pembelajaran ekspositori pada materi trigonometri di kelas X SMA Negeri 1 Binjai Kab. Langkat ditinjau dari penilaian tes kemampuan siswa yang menghasilkan skor rata-rata hitung yang berbeda-beda.

Temuan hipotesis pertama memberikan kesimpulan bahwa: kemampuan pemahaman konsep matematis siswa yang memperoleh model pembelajaran berbasis masalah lebih baik daripada siswa yang memperoleh model pembelajaran ekspositori. Menurut Susanto (2014) pemahaman konsep adalah kemampuan menjelaskan suatu situasi dengan kata-kata yang berbeda dan dapat menginterpretasikan atau menarik kesimpulan dari tabel, data, grafik, dan sebagainya. Memperoleh pemahaman konsep dalam pembelajaran yang dilakukan melalui pengalaman. Dengan pemahaman konsep, kita akan mampu mengadakan analisis terhadap permasalahan untuk kemudian mentransformasikan ke dalam model dan bentuk persamaan matematika, baru kemampuan menghitung diperlukan.

Dengan menerapkan sebuah pembelajaran yang mengedepankan pemberian masalah diawal pembelajaran dengan permasalahan yang kontekstual. Melalui masalah yang diberikan akan memberikan pengalaman belajar yang bermakna bagi siswa dalam menemukan pengetahuan. Dengan pengalaman-pengalaman belajar tersebut mengarahkan siswa lebih memahami matematika. Pembelajaran berbasis masalah ini menuntut siswa untuk melakukan penyelidikan untuk menemukan informasi yang dapat digunakan dalam memecahkan masalah yang akan membentuk pengetahuan siswa. Hal ini tidak ditemukan dalam pembelajaran 
ekspositori yang membuat siswa bersifat tidak aktif, bertumpu pada guru, kurang kreatif dan tidak mandiri. Pembelajaran ekspositori merupakan pembelajaran yang sebagian besar dilakukan penyajian informasi, bukan pembentukan kepribadian siswa.

Temuan hipotesis kedua memberikan kesimpulan bahwa kemampuan pemecahan masalah matematis siswa yang memperoleh model pembelajaran berbasis masalah tidak lebih baik daripada siswa yang memperoleh model pembelajaran ekspositori. Menurut Sternberg dan Ben-Zeev (1996), suatu masalah disebut masalah matematika jika prosedur matematika seperti prosedur aritmatika dan aljabar dibutuhkan untuk memecahkannya. Jadi, masalah matematika adalah suatu masalah yang diterima untuk dianalisis dan mungkin dapat diselesaikan dengan metode matematika. Hal ini berarti, suatu masalah disebut masalah matematika bilamana pemecahan masalah tersebut dapat diperoleh dengan menggunakan metode atau prosedur matematika.

Dengan menggunakan pembelajaran berbasis masalah diasumsikan bahwa kemampuan pemecahan masalah matematis siswa seharusnya lebih tinggi daripada kemampuan pemecahan masalah matematis siswa yang diajar dengan model pembelajaran ekspositori. Namun pada kenyataannya kemampuan pemecahan masalah matematis siswa yang diajar dengan menggunakan pembelajaran berbasis masalah tidak jauh beda dengan kemampuan pemecahan masalah matematis siswa yang diajar dengan menggunakan model pembelajaran ekspositori. Penggunaan model pembelajaran berbasis masalah dan model pembelajaran ekspositori dalam kemampuan pemecahan masalah matematis siswa tidak jauh berbeda nilai rata-ratanya, sehingga model tersebut dapat dikatakan tidak ada yang lebih baik. Kedua model tersebut sama saja untuk menghitung kemampuan pemecahan masalah matematis siswa.

Temuan hipotesis ketiga memberikan kesimpulan bahwa: kemampuan pemahaman konsep dan pemecahan masalah matematis siswa yang memperoleh model pembelajaran berbasis masalah lebih baik daripada siswa yang memperoleh model pembelajaran ekspositori. Menurut Sanjaya (2013) strategi pembelajaran berbasis masalah diartikan sebagai rangkaian aktivitas pembelajaran yang menekankan kepada proses penyelesaian masalah yang dihadapi secara ilmiah. Penggunaan pembelajaran berbasis masalah dapat menciptakan situasi belajar yang menyenangkan, mendorong siswa belajar dan memberikan kesempatan kepada siswa untuk mengkonstruksi konsep-konsep yang dipelajarinya sehingga tercapainya hasil belajar siswa yang baik.

Masalah yang diciptakan untuk siswa menimbulkan rasa ingin tahunya, bagaimana cara menyelesaikannya, konsep yang bagaimana yang diperlukan untuk pemecahan dan metode apa yang tepat digunakan untuk penyelesainnya hal ini akan memberikan pengalaman pembelajaran bagi peserta didik. Hal tersebut akan mendorong siswa menggunakan pengetahuan yang telah dimiliki dan mencari yang perlu diketahui untuk memecahakan masalah tersebut. Sedangkan pembelajaran ekspositori menurut Sanjaya (2013) strategi pembelajaran ekspositori adalah strategi pembelajaran yang menekankan kepada proses penyampaian materi secara verbal dari seorang guru kepada sekelompok siswa dengan maksud agar siswa dapat menguasai materi pelajaran secara optimal. Penggunaan ekspositori merupakan cara pembelajaran mengarah kepada tersampaikannya isi pembelajaran kepada siswa secara langsung. Dengan demikian siswa akan cenderung pasif, tidak adanya dorongan untuk memecahkan masalah dengan inisiatif yang berasal dari dirinya. Hal seperti inilah yang menghambat pemahaman konsep dan pemecahan masalah siswa terhadap matematika.

\section{E. Simpulan}

Berdasarkan hasil penelitian yang telah diperoleh, serta permasalahan yang telah dirumuskan, peneliti membuat kesimpulan sebagai berikut: (1) Kemampuan pemahaman konsep matematis siswa yang memperoleh model pembelajaran berbasis masalah lebih baik daripada siswa yang memperoleh model pembelajaran ekspositori pada materi trigonometri di kelas $\mathrm{X}$ SMA Negeri 1 Binjai Kab. Langkat. (2) Kemampuan pemecahan masalah matematis siswa yang memperoleh model pembelajaran berbasis masalah tidak lebih baik daripada siswa yang 
Wina Alnadrah Pulungan \& Eka Khairani Hasibuan: Perbedaan Kemampuan Pemahaman Konsep dan Pemecahan Masalah Matematis Siswa yang Memperoleh Model Pembelajaran Berbasis Masalah dan Pembelajaran Ekspositori

memperoleh model pembelajaran ekspositori pada materi trigonometri di kelas X SMA Negeri 1 Binjai Kab. Langkat. (3) Kemampuan pemahaman konsep dan pemecahan masalah matematis siswa yang memperoleh model pembelajaran berbasis masalah lebih baik daripada siswa yang memperoleh model pembelajaran ekspositori pada materi trigonometri di kelas X SMA Negeri 1 Binjai Kab. Langkat.

\section{DAFTAR PUSTAKA}

Arikunto, Suharsimi. (2011). Prosedur penelitian: Suatu pendekatan praktik. Jakarta: Rineka Cipta.

Gunantara, G., Suarjana, I.M., \& Riastini, P.N. (2014). Penerapan model pembelajaran problem based learning untuk meningkatkan kemampuan pemecahan masalah matematika siswa kelas V. Jurnal Mimbar PGSD Universitas Pendidikan Ganesha, 2(1), 1-10. doi: http://dx.doi.org/10.23887/jipgsd.v2i1.2058.

Lestari, K.E., \& Yudhanegara, M.R. (2018). Penelitian pendidikan matematika. Bandung: Refika Aditama.

Mawaddah, S., \& Maryanti, R. (2016). Kemampuan pemahaman konsep matematis siswa smp dalam pembelajaran menggunakan model penemuan terimbing (discovery learning). Jurnal Pendidikan Matematika, 4(1), 76-85.

Pemerintahan Indonesia. (2003). Undang-undang no 20 tahun 2003 tentang sistem pendidikan nasional. Jakarta: Sekretariat Negara.

Priansa, D.J. (2017). Pengembangan strategi dan model pembelajaran. Bandung: Pustaka Setia.

Rizkiani, Ahmad, M., \& Lubis, J.R. (2019). Efektivitas penggunaan strategi pembelajaran ekspositori berbantuan macromedia flash 8 terhadap kemampuan pemecahan masalah matematis siswa SMAN 1 Panyabungan Utara. Jurnal Mathedu (Mathematic Education Journal), 2(3), 75-81.

Rusman. (2017). Belajar dan pembelajaran berorientasi standar proses pendidikan. Jakarta: Kencana.

Sanjaya, Wina. (2013). Strategi pembelajaran berorientasi strandar proses pendidikan. Jakarta: Kencana.

Sari, Pramitha. (2017). Pemahaman konsep matematika siswa pada materi besar sudut melalui pendekatan PMRI. Pagaralam: Jurnal Gantang, 2(1), 41-50.

Situmorang, A.S. (2016). Efektivitas strategi pembelajaran ekspositori terhadap pemahaman konsep matematika mahasiswa prodi pendidikan matematika Universitas HKBP Nommensen. Jurnal Suluh Pendidikan FKIP-UHN, 3(2), 109-119.

Sternberg, R.J. \& Ben-Zeev, T. (1996). The nature of mathematical thinking. Mahwah, NJ: Lawrence Erlbaum Associates.

Sumantri, M.S. (2016). Strategi pembelajaran teori dan praktik di tingkat pendidikan dasar. Jakarta: Rajawali Pers.

Susanto, Ahmad. (2014). Teori belajar dan pembelajaran di sekolah dasar. Jakarta: Kencana.

Yelvalinda, Pujiastuti, H., \& Fatah, A. (2019). Pengaruh model pembelajaran problem based terhadap kemampuan pemahaman matematis. Prosiding Seminar Nasional \& Call For Papers Program Studi Magister Pendidikan Matematika Universitas Siliwangi, Tasikmalaya. 